\title{
PHILIPPINES
}

\section{Courageous women in media \\ Marcos and censorship in the Philippines}

\begin{abstract}
When Philippine President Ferdinand Marcos declared Martial Law in 1972, press freedom became the first casualty in the country that once boasted of being the 'freest in Asia'. Printing presses, newspaper offices, television and radio stations were raided and padlocked. Marcos was especially fearful of the press and ordered the arrest of journalists whom he charged with conspiring with the 'Left'. Pressured into lifting martial law after nearly 10 years, Marcos continued to censor the media, often demanding publishers to sack journalists whose writing he disapproved of. Ironically, he used the same 'subversive writings' as proof to Western observers that freedom of the press was alive and well under his dictatorship. This article looks at the writings of three female journalists from the Bulletin Today. The author examines the work of Arlene Babst, Ninez Cacho-Olivares, and Melinda de Jesus and how they traversed the dictator's fickle, sometimes volatile, reception of their writing. Interviewed is Ninez Cacho-Olivare, who used humour and fairy tales in her popular column to criticise Marcos, his wife, Imelda, and even the military that would occasionally 'invite' her for questioning. She explains an unwritten code of conduct between Marcos and female journalists that served to shield them from total political repression.
\end{abstract}

Keywords: Bulletin Today, censorship, gender, history, human rights, press freedom, Manila Daily Bulletin , martial law, media freedom, Philippines, President Marcos

\section{AMY FORBES}

\section{James Cook University, Queensland}

-HE PHILIPPINES has always boasted of having a robust Western-style democracy following independence from American rule in 1946. It was 'the showcase of democracy in the Orient' and its political process is described as an 'amiable, profitable, and socially undisruptive competition for office among the gentry' where competing parties alternated in governing the nation through regular elections (Rosenberg, 1979).

But in 1969, then-President Ferdinand Marcos faced the prospect of a last term in 
POLITICAL JOURNALISM IN THE ASIA-PACIFIC

office as stipulated by the 1935 Constitution. Rocked by protests, allegations of corruption and skyrocketing inflation, Marcos' popularity was at an all-time low.

Following his State of the Nation address on 26 January 1970, he and his wife, Imelda, were booed and heckled as they left the hall of Congress. A makeshift coffin with the word 'demokraskya' draped around it signifying the death of democracy in the country was tossed at the scurrying couple (Bas, 1984). No wonder. Just the year before, the infamous Plaza Miranda bombing killed nine people when two hand grenades were tossed on stage at the political campaign rally of the opposition party, the Liberals. Many candidates on stage, among them incumbent Senator Jovito Salonga, two other senatorial candidates, a vice-mayor and congressman, and the mayoral candidate for the City of Manila were all badly wounded. Marcos was swift to impute responsibility to 'communist' elements in society. He suspended the writ of habeas corpus which then allowed the police to make arrests without warrants and to detain the arrested without charges. It was, one might say, a dress rehearsal for things to come.

The 1970 Constitutional Convention which sought to draw up a new constitution to replace the old one was also rocked by allegations of corruption and bribery by the government. Envelopes filled with money from the presidential Malacañang Palace were allegedly distributed to the delegates to help ensure that a 'Ban Marcos' legislation would be voted down (Gleeck Jr., 1987). A majority of the delegates were already traditional politicians who, not unlike Marcos, were eager to extend their own political careers. The senators and representatives were all looking forward to the opening of the regular session of the legislature on 22 January 1973 (Bas, 1984).

In mid-June 1972, one-time Marcos Nationalista ruling party member Senator Jose Diokno delivered his 'Throne of Bayonets' speech in the Senate where he asserted there was no way Marcos could hold on to power, except illegally (Siak, 2007). In that famous speech, the fiery senator said that even if Marcos were to declare martial law, he should vacate the presidency and turn it over to the Senate president until a new president was elected and sworn in (Celoza, 1997). 'Marcos can create a "throne of bayonets", Diokno said. But how long can he sit on it?' (Mercado, 2013).

Marcos, meanwhile, did have plans to stay in power by any means, legal or otherwise. In the weeks leading up to September 1972, newspapers were full of reports about rallies, protests and demonstrations. The government reported a series of dramatic events to demonstrate that communist and subversive elements were indeed operating in society and that there was imminent danger to the republic. Terrorists were reported to have blown up a police car in August. A series of bombs were set off in downtown Manila department stores, city halls and school campuses. Two people were killed and about a hundred were reported injured following some 16 explosions across the metropolis. The final straw was the alleged ambush by guerrilla forces on then-Defence Secretary Juan Ponce Enrile's two-car convoy on the evening of September 22, further justifying in

196 PACIFIC JOURNALISM REVIEW 21(1) 2015 
Marcos' mind his declaration of martial law (In his own words: Marcos on martial law, 2012). In later years, questions about how real this alleged ambush was would be the subject of inquiry and political intrigue (Yamsuan, 2012).

\section{A manipulated and complicit press}

During the 1960s, the Philippine press was a conflicted press. Like many of its counterparts in newly independent governments of South-east Asia, it had enjoyed an environment of almost total freedom. But unlike its counterpart press in South-east Asia, whose freedoms were soon controlled by their governments which viewed the ultra-libertarian system as incompatible with nationalistic programmes for unity and nation-building, the Philippine press remained uncontrolled, critical and at times, licentious. It also became clear that in Philippine politics, newspapers were valuable political allies that were, sadly, not above bribery. A former editor of the Evening News, Amando Dacanay, quoted in Rosenberg (1979) said: ' ... most newspapers here are extensions of business empires. We are a country where unfortunately, keeping a newspaper is a good defence weapon for big business.'

Marcos had wanted the press on his side. Indeed, during his re-election campaign, he is reported to have poured millions of dollars into public relations campaigns, only to lose his popularity so quickly and so dramatically, especially in the editorial pages. He alternately wooed and threatened the press, often inviting publishers and editors to sumptuous luncheons and dinners at Malacañang Palace only to accuse them of 'fomenting disorder' and 'harbouring Communists and Communist sympathisers' (Rosenberg, 1979). Unable to get them on his side, his government forayed into publishing, putting out a weekly called the Government Report. In its maiden issue, the headline read: 'Can publishers foment disorders?' (Rosenberg, 1979).

So it was that martial law was declared and Filipinos awoke to find themselves without newspapers, radio or television. Martial law, otherwise known as Proclamation 1081, provided the general orders for the government to control media and the dissemination of information. Foreign news agencies and cable and telegraph offices were also shut down.

Columnist Arlene Babst (1982a), who at the time had just completed university, and was exactly four months and three weeks on her first reporting job at Pace magazine of the Evening News, had been working on a robbery story the night before. She woke to find her newspaper shut down along with every other newspaper in the country and her robbery story paling in comparison to the biggest (unreported) story of the declaration of martial law and the arrest of opposition politicians, publishers and journalists.

By midday on September 23, police and the military had rounded up 52 of the targeted 200 persons of interest including Senators Benigno Aquino, Jr, Jose Diokno, and Ramon Mitra (In his own words: Marcos on Martial Law, 2012). Along with them were prominent newspaper publishers, journalists, radio commentators, Constitutional 
POLITICAL JOURNALISM IN THE ASIA-PACIFIC

Convention delegates, a governor, a congressman, and several labour leaders.

Still, the arrested journalists were unperturbed. Journalist and author Hernando Abaya narrates that during the early hours at the Manila military base of Camp Crame where they were held, there was no fear or expectation that the detention was anything but temporary. Instead, he said, there was an air of 'uninhibited excitement and warm camaraderie and stimulating talk' and much backslapping and hearty handshakes among old friends (Gleeck, Jr, 1987). Data collected of the period showed that 8281 people were apprehended and detained in the three months following martial law: 2410 alleged members of subversive groups, 2219 wanted criminals, and 3652 categorised as 'others' (Martial law arrests and detentions by end-1972, 2012). The senators and 22 Manila-based journalists fell under this 'others' category.

Aside from the three senators, publishers and journalists Eugenio Lopez, Jr., Amando Doronila, Chino Roces, Teodoro Locsin, Soc Rodrigo, Luis Mauricio, Napoleon Rama, Roger Arrienda, Jose Mari Velez, Rosalinda Galang and Max Soliven were detained. Also arrested were Congressman Roque Ablan, Rafael Aquino and Gov. Luis Bocalan who was allegedly the country's number one smuggler (Gleeck, Jr., 1987). Labour leaders Bert Olalia and Cipriano Cid national president of the Philippine Association of Free Labor Unions, were also in the group.

But the days turned into weeks, and for some, detention stretched to years. The captors on orders from the Palace were selective on who were let go, and who were detained. The Western press became critical of the arrests and the harsh way Marcos dealt with local journalists. One Newsweek journalist wrote:

When Marcos first arrested hundreds of politicians, journalists and gangsters, it was said that some of the worst men in the country had been locked up with some of the best. The trouble is that by now, many of the worst crooks and cut-throats have been released. The people still in jail are the President's political foes... (Marcos' first 100 days, 1973)

Through Presidential Decree 36 issued in November 1972, Marcos provided a rationale for government censorship, pointing to the need to dismantle what he characterised as the oligarchic structure of media ownership in the country. A Marcos confidant, former head of the Palace press corps and later whistleblower Primitivo Mijares, then said 'press freedom is for the people and not for a few self-appointed publishers, who are in the business and not in the vocation of media' (Rosenberg, 1979). The new order called for the dismantling of media monopolies, most of which not surprisingly had been hostile to Marcos.

Apart from the media, the country's largest corporations were also turned over to Marcos and his allies. The new cronies became the new oligarchs, loyal to and beholden to the Marcos regime. Their new monopolies controlled domestic industrial production and the nation's prime commodities. Breaking his silence in 1974, the elder Eugenio Lopez,

198 PACIFIC JOURNALISM REVIEW 21(1) 2015 
Sr. revealed his family's properties were used as ransom for the release of his son, Eugenio Jr, from detention and had not been sold to the government as Marcos had claimed.

Our properties were given to the Marcos family through its 'front men' in exchange for the release of my son and the safety of our family. Some of our properties are now owned and/or operated by the 'front men' through some 'artificial agreement', legal or illegal. (Aquino, 1999)

As to the press, by the end of 1972 only three daily newspapers were back in operation. The Philippine Daily Express was reportedly financed by Marcos allies, including newly appointed ambassador to Japan, Roberto Benedicto. The Times Journal was owned by Benjamin 'Kokoy' Romualdez, younger brother of the First Lady Imelda Marcos. The third was the Bulletin Today which was originally the Manila Daily Bulletin.

The Manila Daily Bulletin began operation in 1900 and was acquired by industrialist Hans Menzi in 1957. It operated as the Manila Daily Bulletin until the declaration of Martial Law in 1972 when all media was shut down. The story goes that a couple of months after the declaration, Menzi was summoned by Marcos and told to revive the newspaper but under a new name. Menzi promptly arrived at the Palace with two designs, one called the Philippine Daily Bulletin, and the other, Bulletin Today. Marcos approved the latter to which he also scribbled 'ok' on the design blueprint (Mariano, 1995).

In the years that followed, there was a loosening of media control and in 1974, foreign press censorship eased. An issue of Newsweek containing a news article on Muslim dissidents critical of the government was allowed to be circulated. Several other international publications resurfaced with notably favourable stories on the gains made under Marcos' 'New Society'.

The New York Times in June 1974 quoted Marcos as promising an ultimate return to 'complete individual freedom and civil rights' and that he had already 'decongested' the jails of political prisoners (Gleeck, Jr, 1987). It was a common ploy of Marcos to release a few of the detained journalists following meetings with delegations from the International Press Institute to placate the international media.

\section{Lifting of Martial Law}

By the early 1980s, there was renewed pressure on Marcos to lift Martial Law. Pope John Paul II was scheduled to visit the country in February 1982. Even in the face of an increasing number of human rights abuses by the military being reported, Marcos was keen to minimise criticism of his regime during the Pope's visit. The United States had a new president in Ronald Reagan. Reagan was governor of California, and with his wife Nancy had been guests of the Marcoses in 1969. In a state dinner for Marcos in 1982, Reagan reminisced about that first visit: 
POLITICAL JOURNALISM IN THE ASIA-PACIFIC

... tonight we welcome old and good friends to the White House in a visit symbolic of the superb relationship between our two countries. It's a nostalgic occasion for us, as well. Nancy and I often think of our 1969 visit to Manila, when we first experienced that unexcelled Philippine hospitality as the guests of our guests here tonight. (Toasts of President Reagan and President Ferdinand E. Marcos of the Philippines at the State Dinner, 1982)

Perhaps it was as a 'gift' to his long-time friend that Marcos lifted martial law just three days before Ronald Reagan was sworn into office. In declaring the end of martial law, Marcos said that 'anarchy has been successfully checked', and that 'the leftist-rightist rebellion has been substantially contained, its ranks reduced to disorganised bands alienated from the people' (Proclamation 2045, 1981).

At the Bulletin Today, publisher Hans Menzi was keen to regain supremacy over rival newspaper Philippine Daily Express which had amassed the highest newspaper circulation in the country. As Menzi was Marcos' close ally, his newspaper was considered one of the 'crony press'. Many of the male editors and reporters who were critical of Marcos had been imprisoned or had gone into exile. The remaining men in the newsrooms were often co-opted by the government. The women reporters and writers who previously had been sidelined in feature supplements and entertainment pages entered the breach. They challenged the government with reports and editorials that contributed to the groundswell of opposition against the dictator.

One of the Bulletin Today's regular female writers, Arlene Babst, was beginning to gain attention through her column as she 'tweaked prominent noses, teased the selfimportant, and otherwise boldly criticised the regime, the various members of the ruling family and their cronies, showing up the sham of some government programmes and other political foibles' (de Jesus, 2012). Babst had suggested to her publisher Hans Menzi to put on more women writers for the paper's Op-Ed section. Among those invited to write for the newspaper were Ninez Olivares, Melinda Quintos de Jesus and Sylvia Mayuga.

Olivares recalls she met Menzi at a dinner and offered him her services as a columnist. She had been a television newscaster during the martial law years and had been a very visible Marcos critic. Asked to read propaganda stories from the Palace, she would roll her eyes on camera. She said 'They [viewers] all know that you don't like it. It's propaganda. You roll your eyes and have this kind of smirk. That was my way of maintaining my reputation as an independent journalist even under such adverse conditions' (N. Olivares, personal communication, 29 August 2014). Menzi liked the idea of having Olivares as a columnist for the Bulletin because it lent credibility to his newspaper.

Another columnist, Melinda Quintos de Jesus recalled she did not think of herself as a political journalist.

I had no intention of becoming a political critic. I did not feel I could write about politics and shared my misgivings with Arlene who had extended the invitation

200 PACIFIC JOURNALISM REVIEW 21(1) 2015 
POLITICAL JOURNALISM IN THE ASIA-PACIFIC

to me... But in a month's time, I had written my first political piece, questioning the propaganda line of the government's food production programme, dubbed the KKK. (de Jesus, 2012)

Freedom of the press and human rights violations were common themes in the columns the women wrote, unlike their male counterparts who tended to focus on more 'international issues'. For example, on writing about press freedom, Babst wrote:

Press freedom does not mean merely the right to criticise the Marcoses though it certainly should include that right... On the other hand, press control which is still abundantly in operation hereabouts in spite of official disclaimers and naïve readers is the first requirement of anyone who has wants and wants to keep power.

(Babst, 1982b)

She bravely and categorically stated in this piece that press control and censorship were still very much in force in spite of assurances from the dictator to the contrary. On power, she wrote:

Each of us has some measure of power: the beggar has power to curse, the jobless to envy, the kin of murdered folk to hunger for revenge, the hungry to hate, the comfortable to be comfortable, the rich to be rich. Presidents and paupers both have some power to act within their sphere, some only to negate, others to create. (Babst, 1982e)

De Jesus, in recalling her two-year stint at the Bulletin, and later the newsmagazine Veritas, said Marcos was keen to gain credentials as a democrat and they (women writers) inadvertently helped him by challenging censorship:

Marcos held up a copy of Veritas on the US talk show This Week with David Brinkley, to prove that he allowed a free press to criticise him. It was on this same show that he announced he would hold a snap election to prove that Filipinos would keep him in power. (De Jesus, 2012)

Columnist Ninez Cacho-Olivares who had long admired James Thurber's style of humour and Art Buchwald's political satire, adopted this writing approach to poke fun at the foibles of Marcos, Imelda and their cronies. Initially, she used fairy tales and amusing anecdotes about kings with avaricious wives everyone knew were very thinly veiled criticism of Marcos and Imelda. She would write fictional and witty dialogues between inanimate objects such as shadows in a climate of surveillance, or about the longstanding feud between the pen and a sword over who was mightier.

'I am the stronger,' boasted the sword. 'With my strength, I can pulverise the pen.'

'Nay,' the pen answered, 'the speech has been spoke through history.The pen is 
POLITICAL JOURNALISM IN THE ASIA-PACIFIC

mightier than the sword.'

Strange as it may seem, the pen's might found favour with the people...The pens grew in strength and number. More abuses were exposed... Then came the time for the sword to suppress the pen for evermore... With the pen's head on the guillotine block, the blade struck and the pen was stilled. (Olivares, 1982a)

The story does not end here. Olivares ends this medieval tale with a reminder to the reader that there would be other pens to carry on the chivalric ethos.

Ah, but there are other pens that say, 'history shall be rewrit'. They say too that the pen's black fate on more days doth depend, for that day but began the woe others must end. (Olivares, 1982a)

Columnist Melinda Quintos-De Jesus, on truth and propaganda, questioned the official line of the government's response to the alleged massacre of 200 people in the southern province of Leyte. In her column, she questioned how then-Defence Minister Juan Ponce Enrile labelled the reports that appeared in the Far Eastern Economic Review and the WE Forum publications as 'pure fabrication and ... part of the pattern of deception waged by the propaganda arm of the New People's Army' (de Jesus, 1982b). She laments that in this case, the government could only offer the testimony of the very units under suspicion as their defence against the accusations. She ends by admonishing the reader to distinguish truth from propaganda. On corruption, she wrote: 'The problem with corruption now is that we no longer react to it. Because it wears many masks, we no longer recognise its face' (de Jesus, 1982). Brave words. And even braver women journalists pushing the limits. With that first line, de Jesus asserts there was corruption now; a fact long been denied by Marcos under his New Society.

Apart from De Jesus, Babst, and Olivares, a handful of women investigative reporters had also emerged in the early 1980s. Babst singled out Jo-Ann Maglipon who wrote about forgotten provincial towns and the plight of the Indigenous Aeta whose villages came under military siege; Sheila Coronel, who wrote on decades-old landlord-tenant relations; Eleanor Dionisio, who persisted in the investigations behind the murder of Dr Remberto 'Bobby' de la Paz in the province of Samar; and Ma. Ceres P. Doyo, who reported on the murder of chieftain Macli-ing Dulag, who had opposed the construction of the Chico Dam (Babst, 1982d).

Journalist Ceres P. Doyo's career as a journalist is certainly worth recalling. Doyo started out not as a journalist but as a human rights activist. In 1980, the Marcos government, with World Bank funding, had been pushing hard to complete the construction of a dam begun in 1974 along the Chico River in northern Philippines. For more than three decades, the Indigenous people in the Cordillera region had been staunchly opposed to the construction, fearing that the dam's reservoir threatened to inundate 1400 square kilometres of traditional highland villages, rice fields and ancestral domains in the modern

202 PACIFIC JOURNALISM REVIEW 21(1) 2015 
day provinces of Mountain Province, Kalinga and Apayao (Bantayog ng mga Bayani website). Local chieftain Macli-ing Dulag who was also a road maintenance worker for the Department of Public Works and Highways was the recognised spokesperson for the anti-dam opposition. On April 24, 1980, elements of the 4th Infantry Division of the Philippine Army raided his house and killed Macli-ing Dulag and a companion. But no journalist was reporting the murder. Doyo took it upon herself to visit the site, write the story, and submit her work to Panorama, the Sunday magazine of the Bulletin Today.

'Nobody was writing about it, so I wrote it, took my own pictures and sent it to the editor of Panorama, whom I did not know,' Ms. Doyo said.

In hindsight, she said, 'Maybe I was half stupid or half brave.' (Conde, 2011)

At Panorama, feisty and independent-minded editor Letty Jimenez-Magsanoc published Doyo's story. For this, Doyo received a summons from the military on 5 July 1980 ( Lapeña, 2013). Magsanoc came to her defence and began writing scathing editorials against Marcos and his oppressive regime. This eventually led to her being fired as editor of Panorama in 1981 and she would refer to the type of writing the women did as 'suicide journalism' (Doyo, 2012).

This is not to say there were no other brave media during this period. During the waning years of Martial Law when restrictions were somewhat more relaxed, satirical programmes on television did dare poke fun at the regime. These included Sic O'Clock News, Hanggang sa Susunod na Kabanata (Until the Next Chapter) and the very shortlived, Mr Minister. Mr Minister lasted all of two episodes before it was unceremoniously withdrawn from the small screen. De Jesus (1982) reviewed the programme in her column and reported that the RPN 9's general manager (who also conceived the show), conceded it may not have been commercially viable due to its potential for controversy. One can only assume that the Palace did not take kindly to seeing government ministers parodied and portrayed as ineffectual on a weekly television programme.

For print journalists, censorship came in the form of 'friendly invitations' by the military. Bulletin publisher Hans Menzi, himself, was occasionally called in to the Palace whenever Olivares or any of her other intrepid female colleagues wrote something controversial or irritating to Marcos and Imelda.

On one occasion, Olivares turned the tables on her interrogators, making them the lead players in her satirical piece on her dread of being 'interviewed'. In the piece, she says she wanted to refuse the invitation but was caught in a Catch-22 situation. She could not say no even to the most personal of questions such as, 'Gasp! How she ran her household?' 'I adhere to democratic principles, I answered, flashing a smile in return. Democracy is a byword in my household,' (Olivares, 1982b). Using her wit and not-so veiled parallelisms to how Marcos ran his government, that is, appointing relatives and friends to key positions, Olivares claimed to do the same in her household. 
POLITICAL JOURNALISM IN THE ASIA-PACIFIC

'All the members of your family seem to have positions in your household. True or False?' 'That's not accurate,' I said. 'My nephews, nieces, brothers-in-law and friends are involved in the running of my household too, and they don't get any allowance from me either, because their services are voluntary.' (Olivares, 1982b)

Clearly, her response to the interrogator sounded suspiciously like the Dictator's claim that family and friends did not enjoy any benefits from being in government. Certainly not Imelda's younger brother Benjamin 'Kokoy' Romualdez, who was appointed ambassador to China, Saudi Arabia and the United States while serving as Leyte province governor. He became owner and board member of a range of companies, banks and utilities seized by the Marcos regime during Martial Law. An older brother, Alfredo, came to head the casino gambling industry.

Following the publication of this story, Olivares says she received a second invitation from her clearly annoyed interrogators. These interrogations usually lasted hours, were held inside closed doors and the interrogators were high-ranking military officials (Doyo, 2012). Olivares asked them if they 'got it' [the inside joke] and they sheepishly had to admit they did and found the writing humorous. 'What I was doing was skirting around it [censorship]. Babst and the rest could write about it but only indirectly' (N. Cacho-Olivares, personal communication, 2014).

There were occasions, though, when even the straight-writing Babst would join the fun and train her sights on the First Lady, Imelda. In her column, Let the lady do the talking (Babst, 1982c), Babst reviews an interview of Imelda that had appeared in Newsweek magazine. Imelda Marcos had granted the interview to Newsweek's Bangkok bureau chief Seth Mydans and Canadian foreign correspondent Richard Vokey whom Babst would later marry.

Babst writes, with her tongue firmly in cheek, that the only way the intelligent reader could assess Imelda Marcos' genuine quality was to let the lady tell her story in her own words. What follows is the most hilarious and cringe-worthy account the First Lady had ever given of herself. On her role as First Lady, Marcos said: 'My role as First Lady is to be "S" and "S" - star and slave. As a star, to give the people a standard to reach for. As a slave, to lift people from the gutter.' On her lavish lifestyle, she said: 'I am always criticised for my jewellery; for what they call my lavish lifestyle, my extravagant frivolity. But I have always been criticised for my sense of beauty. I will continue to be a soldier for beauty because that is the only thing which feeds the human spirit.' And perhaps her most (in)famous statement yet on the Filipino people: 'Yes, they are living in slums and hovels. But what counts is the human spirit, and they are smiling. For me the real index of this country is my smiles of the people, not the economic index.' Babst asks cheekily: 'Will anyone dare censor the First Lady's words?' 


\section{The women are silenced}

By 1983, Marcos had had enough of these audacious women. Menzi was summoned yet again to Malacañang Palace over the women's writing. Mariano (1995) in his oral history of the Manila Bulletin writes that Menzi was a realist. If Marcos became really angry, they would all be out of work. He writes: 'The Bulletin was so liquid that it was able to pay for the construction of its present building in cash and without incurring any debts. He [Menzi] didn't want to lose that because of some hotshot columnist' (Mariano, 1995).

It is also worth recalling that in 1972, when journalists were being rounded up, Menzi had 'surrendered' his society columnist Amelita Reysio-Cruz to the authorities on October 3. Reysio-Cruz was sought by authorities because she had made Imelda angry over her writings about Marcos' affair with American B-movie actress Dovie Beams two years earlier. She was also openly contemptuous of Imelda who she nicknamed 'Imeldita' and Imelda in turn, labeled her 'Animalita' (Mariano, 1995). She was to be detained for almost three months and released only due to illness.

In 1983, Menzi had to let go of Olivares and de Jesus, and eventually Babst who was then the one regular columnist. Olivares narrates that once before, Menzi had requested her to tone down her writing or write about something other than political issues while Marcos 'cooled down'. She had acquiesced.

It was around 1983, and I was really getting to be too direct but still on the humourous side. So he [Menzi] said again, 'Ninez, can we do it again?' I said, 'I did it once. I'm willing to do it again for your sake but I said what kind of journalist would I be if every time the president is mad at me for writing this stuff, I stop. And when he's cooled down, I write again?'

'But I'm not firing you,' he said.'I know, but it's better for the both of us if we just part ways.' He accepted that. (N. Cacho-Olivares, personal communication, 2014)

Olivares moved to Business Day where publisher Raul Locsin gave her a 'no censorship' guarantee.

How did the women journalists manage Marcos and censorship during this period when their male counterparts could only write about innocuous topics as OPEC oil prices, barangay (local body) meetings, traffic jams and petty burglaries?

Olivares explains about an unwritten code relating to Filipino male machismo. She says Marcos was of the old school and would never dare engage a woman in a public quarrel.

The thing with Marcos that a lot of people haven't realised, and why women journalists got away with it - Marcos followed tradition or the code of conduct of Filipino males. A man never quarrels with a woman. His stature and esteem go down. It's never done. You can quarrel with a woman in private but never in public. On the other hand, the unwritten code says also that women can fight each other even if 
POLITICAL JOURNALISM IN THE ASIA-PACIFIC

they pull each other's hair out. It is acceptable in the Philippine context (N. Cacho-

Olivares, personal communication, 2014).

Another reason was that the women were not the family breadwinners. Olivares said she could lose her job and still have her husband support her. This may serve to explain why the women had more fire in their bellies than their male counterparts. De Jesus adds to the gender argument: 'It also helped that the custom and convention had kept us mostly out of the old boy cliques which could have made it more difficult to break away from the pattern of press controls' (de Jesus, 2012).

De Jesus adds that being deeply identified with the establishment (most of the women were products of a Catholic education), it was virtually impossible to accuse them of subversion, communism or terrorist movements, and were considered 'safe'. But being safe was never an option for the women.

We were not victims. Ours was a success story... It would have caused more pain to have kept to our comfort zones, to be blind and to be silent to the truths that our sources shared with us. It would not have been easy to restrain the impulse to report and to comment, to choose instead not to be involved. (de Jesus, 2012)

\section{Conclusion}

Beneath the highly 'macho' facade of the Filipino male is a strong matriarchal foundation where women are mature, entrepreneurial and persevering. The family system is marked by cooperation, loyalty, and dutifulness to elders, and women maintain a highly respected position. Traditionally depicted as coy, retiring, and subservient, the Filipina woman is also supposed to have power and influence unofficially and in private (Castillo, 1976). In pre-Spanish times, women had the same civil and political rights as men (Aguilar, 1989). Following colonisation, the effects of ideologies of colonial domination served to construct a Filipino womanhood perpetuating the illusion of male dominance and female submission. But as shown through the experience of the women journalists writing during what Ceres Doyo (2012) describes as 'years of writing dangerously', women journalists can rejoice in the knowledge that for a brief period, they were able to rattle the status quo:

We all emerged uncracked. Ah, the stories we narrated to one another. What did wethe women writers-do next? Having gotten all the interrogators' names, we plotted in the dead of night and built a case against them with the help of the Flag and Mabini lawyers. We strode into a jam-packed Supreme Court to question the so-called National Intelligence Board, a creation of the Marcos military dictatorship to cow writers. We won. The respondents said they were done with it anyway. Duuuh...

Following the ouster of Marcos in 1986, Ceres P. Doyo continued to write and served on the board of the Philippine Center for Investigative Journalism for many years until 2010.

206 PACIFIC JOURNALISM REVIEW 21(1) 2015 
She has also written a number of books about her martial law experiences, among them, Journalist in Her Country (1993) and Human Face: A Journalist's Encounters and Awakenings (2013). Today, she is a staff writer and columnist on the Philippine Daily Inquirer where she covers a variety of issues and writes special reports, feature stories and a weekly column, Human Face.

Of the other women journalists, Sheila Coronel worked for the Manila Times as a political reporter, and also wrote special reports for The Manila Chronicle. With eight other journalists, she co-founded the Philippine Center for Investigative Journalism (PCIJ) in 1989. PCIJ is a non-profit media organisation whose aim is to produce wellresearched, high-impact investigative reports that help build the media's credibility and gain public support. She became the first Filipina to win the Ramon Magsaysay Award for Journalism, Literature, and Creative Communication Arts in 2003. She is currently academic dean at Columbia University where she is also director of the Toni Stabile Center for Investigative Journalism.

Eleanor Dionisio is associate director of the John J. Carroll Institute on Church and Social Issues. She continues to write for the Philippine Daily Inquirer on church matters, particularly the role of the Catholic Bishops' Conference of the Philippines (CBCP). The CBCP was created following the Second Vatican Ecumenical Council (Vatican II) and is a grouping of bishops of the Philippines who represent the Christian faithful to 'promote the greater good which the Church offers to humankind, especially through forms and programmes of the apostolate which are fittingly adapted to the circumstances of the time and place' (Robredillo, 1996). In its early years, the CBCP oscillated between the old and the new ecclesiological paradigm. Following martial law, more progressive members saw their role as 'more than social charity and development' and then-Cardinal Jaime Sin instituted a policy of 'critical collaboration' with the government that in actuality was more 'critical and prophetic than collaborative' (Robredillo, 1996).

Jo-Ann Maglipon continues to write and is YES! magazine and Philippine Entertainment Portal (PEP) editor-in-chief. In 2011, she was appointed by the President to serve as a member of the Movie and Television Review and Classification Board (MTRCB) Appeals Committee, tasked to assist and to recommend to the President on 'the proper disposition of appeals from the decisions of the MTRCB disapproving or prohibiting the public exhibition of a motion picture or television programme' (Godinez, 2011).

As for Babst, she revelled in the power of the women journalists and celebrated the friendship she had with the Bulletin women she considered her friends rather than rivals. She wrote:

I thank God for being born at a time when strong women can express themselves, do things, travel, live with whomever they choose with or without marriage, control the reproductive functions of their own bodies, and come to their own hard-won conclusions about God or the American bases or Ferdinand Marcos. (Babst,1982c) 
POLITICAL JOURNALISM IN THE ASIA-PACIFIC

Babst lives in Vancouver, Canada, with her husband and fellow journalist, Richard Vokey.

After the Bulletin, Melinda Quintos de Jesus became deputy editor and columnist of the newsmagazine Veritas Newsweekly, an 'alternative press'. Later, she founded and became executive director of the Center for Media Freedom and Responsibility (CMFR), a private, non-stock, non-profit foundation that focuses on the protection of press freedom and the establishment of a framework of responsibility for journalism practice. Among its flagship programmes is work on ethics and social responsibility in which the CMFR conducts media monitoring and review, as well as special training programmes. It also maintains a database of journalist killings and conducts analysis of the 'culture of impunity' that has resulted in specific recommendations to counter this disturbing reality (2015, CMFR).

After working at other leading newspapers, Ninez Cacho-Olivares founded and became publisher of The Daily Tribune, a contrarian broadsheet that has been critical of every president that followed Marcos. The dictator himself died in exile in Hawai'i in 1989 but his wife, Imelda, is still active in Philippine politics along with two of her three children, Imee Marcos who is Governor of her father's bailiwick Ilocos Norte, and Ferdinand 'Bongbong' Marcos, Jr. who is a Senator in the 16th Congress. The Daily Tribune has reported continuing cases of large-scale corruption under the new presidents such as the granting of huge government contracts without due process, presidential abuse of power reminiscent of the dictator, and nepotism. In February 2006, the offices of The Daily Tribune were searched by police during a plot to topple the Arroyo government that resulted in the imposition of a State of Emergency. In 2008, Olivares was found guilty of libel by a Makati Regional Trial Court and sentenced to a minimum of six months and a maximum of two years imprisonment (Aurelio, 2008). She was granted bail and continues to publish her newspaper to this day.

Journalism remains a profession under siege not just in the Philippines but around the world. Journalists, men and women, continue their work in the midst of personal struggles, criticism, potential harm or death. But such is the responsibility that comes with the profession that they continue the task of serving the interests of the common people, protecting and nurturing fundamental freedoms and ultimately, helping people uncover where the truth lies.

\section{References}

Aguilar, D. (1989). The social construction of the Filipino woman. International Journal of Intercultural Relations, 13, 527-551.

Aquino, B. (1999). Politics of plunder, the Philippines under Marcos [2nd Ed.]. Manila, Phil.: University of the Philippines, Great Trade Book and UP College of Public Administration.

Aurelio, J. (2009, June 5). Tribune publisher Olivares guilty of libel. Philippine Daily Inquirer.

208 PACIFIC JOURNALISM REVIEW 21(1) 2015 


\section{POLITICAL JOURNALISM IN THE ASIA-PACIFIC}

Retrieved on November 17, 2014, from http://newsinfo.inquirer.net/breakingnews/metro/ view/20080605-140877/UPDATE-2-Tribune-publisher-Olivarez-guilty-of-libel

Babst, A. (1982a, September 21). Has it been ten years? Bulletin Today, p. 6.

Babst, A. (1982b, April 30). Press freedom and press control. Bulletin Today, p.6.

Babst, A. (1982c, September 15). Let the lady do the talking. Bulletin Today, p. 6.

Babst, A. (1982d, June 2). Women and investigative reporting. Bulletin Today, p. 6.

Babst, A. (1982e, July 25) Power. Bulletin Today, p. 6.

Bas, Sr., M. (1984). Philippine martial law. New York, NY: Vantage Press, Inc.

Castillo, G. T. (1976). The Filipino woman as manpower: The image and the empirical reality. Laguna, Phil.: University of the Philippines.

Celoza, A. (1997). Ferdinand Marcos and the Philippines - The political economy of authoritarianism. Westport, CT.: Praeger Publishers.

CMFR Website. (2015). Flagship programs. Retrieved February, 26, 2015, from www.cmfr-phil. org/flagship-programs/

Conde, C. (2011, May 16). The female factor: In Philippine newsrooms, the women rule. Retrieved February 26, 2015, from http://carlosconde.com/2011/05/17/the-female-factor-in-philippinenewsrooms-the- women-rule/

Doyo, C. (2012, September 2). Better dead than read: The years of writing dangerously. Human Faces by Ceres. Retrieved November, 17, 2014, from http://humanfacebyceres.blogspot.com. $\mathrm{au} / \mathrm{search} ? \mathrm{q}=$ olivares\&submit $=$ Search

Gleeck Jr, L. (1987). President Marcos and the Philippine political culture. Manila; Phil.: Loyal Printing, Inc.

De Jesus, M. (2012, March 7). Women in media. In Medias Res. Retrieved November 9, 2014, from www.cmfr-phil.org/inmediasres/women-in-media/

De Jesus, M. (1982, January 21). Fear of laughter. Bulletin Today, p. 6.

Dulag, Macli-ing. Bantayog ng mga Bayani website. Retrieved on February 25, 2015, from www. bantayog.org/node/96

Godinez, B. (2011, March 7) PNoy appoints entertainment editor Jo-Ann Maglipon and director Mel Chionglo to MTRCB Appeals Committee. PEP. Retrieved February 26, 2015, from http:// www.pep.ph/news/28582/PNoy-appoints-entertainment-editor-Jo-Ann-Maglipon-and-directorMel-Chionglo-to-MTRCB-Appeals-Committee

In his own words: Marcos on Martial Law (2012, September 21). ABS-CBN. Retrieved on November 12, 2014, from http://www.abs-cbnnews.com/-depth/09/21/12/his-own-wordsmarcos-martial-law

Lapena, C. (2013, March 1). Through Marcos years and libel suits, women write on. GMA News. Retrieved on February 25, 2015, from www.gmanetwork.com/news/story/297216/lifestyle/ literature/through-marcos-years-and-libel-suits-women-write-on

Marcos' first 100 days (1973, January 22). Newsweek, p. 49.

Mariano, G. (1995, January). Manila Daily Bulletin. Scribd. Retrieved on November 27, 2014, from www.scribd.com/doc/54483950/Manila-Bulletin\#scribd

Martial law arrests and detentions by end of 1972. (2012, September 23). IRAIA. Retrieved on November 19, 2014, from http://wiki.iraia.net/mw/index.php?title=Martial_law_arrests_and detentions by end-1972

Mercado, J. (2013, August 26). When the strong weep. Philippine Daily Inquirer. Retrieved on December 4, 2014, from http://opinion.inquirer.net/59745/when-the-strong weep\#ixzz3PPaIAb8v

Olivares, N. (1982a, January 27). The pen and the sword. Bulletin Today, p. 6.

Olivares, N. (1982b, September 23). Interviews. Bulletin Today, p. 6. 
POLITICAL JOURNALISM IN THE ASIA-PACIFIC

Olivares, N. (1982c, September 17) The true, the good, and the beautiful. Bulletin Today, p. 6. Proclamation No. 2045. (1981, January 17). Proclaiming the termination of the state of martial law throughout the Philippines. Official Gazette. Retrieved on November 12, 2014, from www. gov.ph/1981/01/17/proclamation-no-2045-s-1981/

Robredillo, L. Fr. (1996, January 24). The challenges of the times and the CBCP's Responses: An historical essay on the Catholic bishops' conference of the Philippines. CBCP Online. Retrieved on February 25, 2015, from http://cbcpwebsite.com/

Rosenberg, D. (Ed.) (1979). Marcos and martial law in the Philippines. Ithaca, NY: Cornell University Press.

Siak. (2007, December 12). Rethinking nationalism: The legacy of Jose Wright Diokno. Dissent. Retrieved on December 18, 2014, from http://theotherdissent.blogspot.com.au/2007/12/ rethinking-nationalism-legacy-of-jose.html

Toasts of President Reagan and President Ferdinand E. Marcos of the Philippines at the state dinner (1982, September 16). Retrieved on January 4, 2015, from www.reagan.utexas.edu/ archives/speeches/1982/91682f.htm

Yamsuan, C. (2012, September 30). Enrile on fake ambush: 'For real'. Philippine Daily Inquirer. Retrieved on November 15, 2014, from http://newsinfo.inquirer.net/279806/enrile-on-fakeambush-for-real

Dr Amy Forbes is a senior lecturer in journalism and communication at James Cook University in Queensland, Australia. She is also a journalist who has worked across television, print and online platforms. She received a Fulbright scholarship to the United States in 1991 and is the recipient of a 2014 Office for Learning and Teaching award for Outstanding Contributions to Student Learning for leadership and excellence in developing and delivering a pioneering WIL-based curriculum in Multimedia Journalism at JCU. An earlier version of this article was presented at the PJR 2014 conference 'Political journalism in the Asia-Pacific' at AUT University, Auckland, on 27-29 November 2014.

amy.forbes@jcu.edu.au

210 PACIFIC JOURNALISM REVIEW 21(1) 2015 